\title{
Forgotten natural enemies: Interactions between coccinellids and insect-parasitic fungi
}

\author{
HeLen E. ROY ${ }^{1}$ and Ted E. COTTRELL ${ }^{2}$
}

\begin{abstract}
${ }^{1}$ NERC Centre for Ecology and Hydrology, Monks Wood, Huntingdon, Cambridgeshire, PE28 2LS, UK; e-mail: hele@ceh.ac.uk ${ }^{2}$ USDA, Agricultural Research Service, Southeastern Fruit and Tree Nut Research Laboratory, 21 Dunbar Road, Byron, GA 31008 USA; e-mail: Ted.Cottrell@ars.usda.gov
\end{abstract}

\begin{abstract}
Key words. Entomopathogenic fungi, ladybeetles, ladybirds, Coccinellidae, Beauveria bassiana, Hesperomyces virescens
\end{abstract}
\begin{abstract}
The role of predators and parasitoids in the regulation of insect populations is widely reported in the context of both pest and non-pest insects. However, this is not the case for pathogens (entomopathogens). Indeed, most studies on insect life history refer only to predators and parasitoids when considering natural enemy guilds, even though naturally occurring entomopathogens are undoubtedly more diverse and widespread. This is certainly the case with the Coccinellidae; the natural enemies of coccinellids have been the subject of a number of review articles but pathogens receive only brief mention. In this review we attempt to address the balance and consider the interactions of natural populations of Coccinellidae with entomopathogenic fungi. Most research on entomopathogens and Coccinellidae focuses on the non-target impact of biorational insecticides against coccinellids and the impact of fungal infections upon aggregations of overwintering coccinellids; with the former overwhelmingly dominating the literature. Given the prominence of coccinellids in classical and conservation biological control, it is surprising that studies have not measured the natural impact of pathogenic fungi upon introduced species or natural populations of Coccinellidae, as has been done with numerous insect pest species. Here we review the literature on the intriguing interactions between coccinellids and fungal pathogens. We examine the literature on direct infection (sub-lethal and lethal) of coccinellids by pathogenic (Beauveria bassiana, Metarhizium anisopliae, Paecilomyces fumosoroseus) or parasitic (Hesperomyces virescens). We also consider the role of intra-guild predation (on the aphid-specific fungus Pandora neoaphidis and Beauveria bassiana) and finally indirect interactions such as coccinellids dispersing $P$. neoaphidis. We suggest that fungal pathogens are all too often forgotten natural enemies and future research should address the profound absence of knowledge in this field.
\end{abstract}

\section{INTRODUCTION}

There have been considerable advances in the field of insect pathology over the last few decades, but the role of pathogens (entomopathogens) as natural enemies of nonpest insects is seldom considered. Indeed, most studies on insect life history refer only to predators and parasitoids when considering natural enemy guilds, even though naturally occurring entomopathogens are undoubtedly more diverse and widespread (Lacey et al., 2001); 50\% of living organisms are microbial (Watson et al., 1995) and insect pathogens are ubiquitous in both above and belowground ecosystems (Hajek, 2004).

Coccinellids are attacked by a suite of natural enemies (Majerus, 1994; Hodek \& Honěk, 1996; Roy et al., 2006a, b) including: predators [such as: the predatory bug Deraeocoris ruber L. (Hemiptera: Miridae)], a hymenopteran parasitoid [Dinocampus coccinellae (Schrank) (Hymenoptera: Braconidae)], dipteran parasites [such as Phalacrotophora fasciata Fallén (Diptera: Phoridae)], a mite [Coccipolipus hippodamiae (McDaniel \& Morril) (Acari: Podapolipidae)], various male-killing bacteria (Wolbachia, Spiroplasma, Rickettsia) and insect pathogenic fungi [such as Hesperomyces virescens Thaxter (Ascomycota: Laboulbeniales) and Beauveria bassiana (Balsamo) Vuillemin (Ascomycota: Hypocreales)]. The role of natural enemies in regulating coccinellid populations generally requires more research, however, this is particularly the case for fungal pathogens, which are widely regarded as important natural enemies of coccinellids (Majerus, 1994; Hodek \& Honěk, 1996) but the relationship is very poorly understood. We suggest that fungal pathogens are all too often forgotten natural enemies and future research should address the profound absence of knowledge.

Much of the literature in this field is in relation to the impacts of fungal-based biorational pesticides on nontarget insects such as coccinellids (James et al., 1995; Pingel \& Lewis, 1996; Todorova et al., 1996; Roy \& Pell, 2000; Smith \& Krischik, 2000; Pell \& Vandenberg, 2002). Considerably less information exists on coccinellids and their interactions with naturally-occurring fungal pathogens, even though fungi, such as B. bassiana, are documented as major mortality factors of overwintering coccinellids (Iperti, 1966; Ceryngier \& Hodek, 1996; Barron \& Wilson, 1998; Ormond et al., 2006).

In this paper we aim to review our current understanding of the interactions between coccinellids and fungal pathogens and to suggest future research directions and priorities. This review was initiated after discussions at the Aphidophaga 10 meeting (Athens, 2007) in response to two papers on the interactions between fungal pathogens and coccinellids (Cottrell \& Shapiro-Ilan, 2008; Roy et al., 2008a, b). 


\section{TAXONOMY}

Entomopathogenic fungi are common natural enemies of arthropods Worldwide. Fungal systematics, particularly at the higher levels of classification, is continually being reviewed and restructured (Hibbett et al., 2007). Hibbett et al. (2007) propose a system of classification for all groups of fungi based on recent molecular phylogenetic studies. There are over 700 species of insect pathogenic fungi and these can be found within two main groups: phylum Ascomycota (subkingdom Dikarya) and the order Entomophthorales from the subphylum Entomophthoromycotina.

The Entomophthorales, obligate pathogens of arthropods, are an extremely important group of insect pathogens historically placed within the Zygomycota. However, the Zygomycota is not an accepted phylum within the revised classification (Hibbett et al., 2007). Therefore, the Entomophthorales have not been assigned a phylum in the current classification but will be pending resolution of clades from the Zygomycota (Hibbett et al., 2007).

The taxonomy of the Ascomycota is more clearly defined and contains two major orders: Hypocreales (class: Sordariomycetes; subclass: Hypocreomycetidae) and Laboulbeniales (class: Laboulbeniomycetes). It is worth noting that the ascomycete fungi were previously divided into two groups: Ascomycota and the Deuteromycota. The Deuteromycota were known as the Fungi Imperfecti (Deuteromycota: Hyphomycetes) and were species for which no sexual stage was known. However, morphological and molecular studies have demonstrated that some of these "imperfect fungi" are anamorphs (asexual forms) of the Ascomycota (order: Hypocreales; family: Clavicipitaceae). Throughout this paper we will refer to the classification proposed by Hibbett et al. (2007).

Although the taxonomy of these fungi is in a dynamic state the basic biology has been well studied. The general life cycles of these fungi are remarkably similar despite their taxonomic diversity (Roy et al., 2006a). Entomopathogenic fungi produce infective spores (conidia) that attach to, germinate, and penetrate the cuticle of their host. Therefore, unlike viral and bacterial pathogens there is no requirement for ingestion of fungal spores. Once within the host they proliferate as single- or multicelled structures (protoplasts, blastospores, hyphal bodies) utilising the nutritional resources of their hosts, ultimately killing them and producing more infective conidia for transmission or resting structures for persistence (such as sexual or asexual resting spores, chlamydospores or mummified hosts).

The abiotic and biotic environment strongly influences fungal activity; high humidity (in excess of 95\%) is required for conidium germination, infection, and sporulation, and the speed of kill is influenced by temperature. The specific ecology, physiology, and life cycles of these fungi vary and reflect adaptations to overcome environmental limitations and the host's defenses. Species in the order Entomophthorales exhibit a continuum of adaptations including dispersive, actively discharged conidia produced externally after host death through to sporula- tion prior to host death in species which require continued host activity to ensure conidia dispersal (Roy et al., 2006a). Species in the Entomophthorales do not produce toxins as part of the infection cycle and are obligate pathogens. They are characteristically biotrophic and have a narrow host range among foliar arthropods. They are not known to be pathogens of coccinellids.

In contrast two Hypocrealean (Ascomycota: Claviciptiaceae) fungi have been found infecting ladybirds: Metarhizium anisopliae (Matschnikoff) (Ginsberg et al., 2002) and B. bassiana (James et al., 1995; Cottrell \& ShapiroIlan, 2003; Roy et al., in press). Hypocrealean fungi are hemibiotrophic, switching from a parasitic, biotrophic phase in the haemocoel to a saprophytic phase colonizing the body after death. The most aggressive strains of Hypocreales achieve host death usually by the production of secondary metabolites. Conidia are not actively discharged. Species belonging to the order Hypocreales have characteristically broad host ranges when associated with soil-inhabiting arthropods in temperate regions. Similar to the Entomophthorales, the Hypocreales produce resting structures for survival in the absence of new hosts or under adverse environmental conditions.

Another important group of fungi in relation to coccinellids is the Laboulbeniales (Ascomycota: Laboulbeniaceae). There are estimated to be between 10,000 and 50,000 species of Laboulbeniales on Coleoptera worldwide (Weir \& Hammond, 1997). Smaller numbers are thought to be associated with other insect orders (Blattodea, Dermaptera, Diptera, Hemiptera, Hymenoptera, Isoptera, Orthoptera and Thysanoptera) and also from noninsect hosts (Acari and Diplopoda). These intriguing fungi are obligate ectoparasites that infect many coccinellids (Thaxter, 1931; Nalepa \& Weir, 2007) occurring from the tropics to the sub-Antarctic on both terrestrial and aquatic hosts (Santamaria, 2001; Harwood et al., 2006).

Most laboulbenialean fungi have few detrimental effects on their hosts (Weir \& Beakes, 1996) but a few negative fitness effects have been documented including those that are considered responsible for declines in Chilocorus bipustulatus L. (Coleoptera: Coccinellidae) in Israel (Kamburov et al., 1967). Laboulbeniales generally do not penetrate the insect cuticle. However the most commonly reported laboulbenialean on coccinellids, $H$. virescens does exhibit rhizoidal penetration into the host body by production of a circular appressorium, which attaches and penetrates the host cuticle (Weir \& Beakes, 1996). Even though this fungus invades the cuticle there are no known deleterious impacts on the host (Nalepa \& Weir, 2007). It is hypothesised that heavy infections could impede flight, foraging and mating but this requires further investigation.

\section{DIRECT INFECTION}

\section{Physiological v. Ecological Susceptibility}

The physiological host range of an entomopathogen typically includes those insect species susceptible to the pathogen when assayed under laboratory conditions. Likewise, the ecological host range of an entomopathogen includes those insect species susceptible to the 
pathogen under field conditions. Comparing the physiological and ecological host range of a pathogen is difficult. Many factors affecting pathogenicity under both laboratory and field conditions must be taken into account to make sense of how physiological susceptibility relates, if at all, to ecological susceptibility. Studies examining pathogen host range generally show that physiological susceptibility greatly exaggerates ecological susceptibility (Hajek et al., 1995, 1996; Solter \& Maddox, 1998).

Factors resulting in the broad physiological host range versus a much narrower ecological host range can include pathogen dosage, environmental conditions, and the likelihood of encounter between pathogen and potential host. Laboratory bioassays use high doses of inoculum against test specimens under conditions generally favourable to the pathogen. In the field, lower doses of the pathogen would generally be encountered under variable environmental conditions, not always conducive to the pathogen (James et al., 1998). Undeen \& Maddox (1973) comment that laboratory infection of the corn earworm, Helicoverpa zea Boddie (Lepidoptera: Noctuidae), with a microsporidian known from mosquitoes (Diptera: Culicidae) was not likely to occur under field conditions due to the high susceptibility of that water-adapted pathogen to desiccation. Interestingly, our knowledge of the physiological and ecological susceptibility of coccinellids to the laboulbenialean fungus $H$. virescens is just the opposite. Less is known about the physiological host range of $H$. virescens attacking coccinellids compared with its known ecological host range (Harwood et al., 2006).

The similarities and differences in the physiological versus ecological host range of entomopathogenic fungi attacking coccinellids are not known. As previously noted, little is reported in the literature regarding the prevalence of fungal infection in natural populations of coccinellids other than their impact upon overwintering populations. Differential susceptibility of coccinellid species to fungi is known from laboratory studies but corroborating field studies are lacking (Cottrell \& ShapiroIlan, 2003; Roy et al., 2008b).

Cagán̆ \& Uhlík (1999) demonstrated pathogenicity of B. bassiana strains originally isolated from Ostrinia nubilalis Hubner (Lepidoptera: Pyralidae) to Coccinella septempunctata L. (Coleoptera: Coccinellidae) and to Propylea quatuordecimpunctata (L.) (Coleoptera: Coccinellidae), but suggested field susceptibility of the coccinellids would be different due to differences in pest and coccinellid behaviour that would likely result in less contact between the pathogen and coccinellids. Although laboratory studies will tend to overestimate the ecological host range of pathogens, it is possible to demonstrate the lack of susceptibility to a pathogen under laboratory conditions. Even though $B$. bassiana can infect many different insect species across many insect orders, a specific $B$. bassiana isolate collected from an infected insect may have a very narrow host range (Tanada \& Kaya, 1993, Federici \& Maddox, 1996). For example, the exotic Harmonia axyridis (Pallas) (Coleoptera: Coccinellidae) was never susceptible to either B. bassiana [isolated from Olla v-nigrum (Mulsant) (Coleoptera: Coccinellidae)] or the entomopathogenic nematode Heterorhabditis bacteriophora Poinar (Rhabditia: Rhabditidae) in laboratory trials (Cottrell \& Shapiro-Ilan, 2003, 2008; Shapiro-Ilan \& Cottrell, 2005). Using a different fungal pathogen, James \& Lighthart (1994) reported that Nomuraea rileyi (Farlow) Samson (Ascomycota: Moniliales) was not pathogenic to Hippodamia convergens Guerin-Meneville (Coleoptera: Coccinellidae) under laboratory conditions. Thus, the lack of physiological susceptibility should be a reliable indicator that a specific strain or isolate of a pathogen will be highly unlikely to infect under field conditions.

\section{Studies on natural populations}

Ceryngier \& Hodek (1996) reported that data on the prevalence of entomopathogens in natural populations of Coccinellidae are scarce. More than a decade later this remains true. The vast majority of data concerning the impact of entomopathogens upon coccinellids is from the laboratory. Most field data concerns the impact of commercially-available, biological insecticides upon nontarget coccinellid species. Data concerning the impact of pathogens upon natural populations of coccinellids is mostly from studies that have examined the effect of fungal diseases during winter. Aggregations of overwintering coccinellids allow for easy access to large samples of coccinellids within a discrete time interval.

Kuznetsov (1997) reviewed research on pathogens attacking coccinellids in the Primorsky Territory of Russia where the decimation of the herbivorous coccinellid Henosepilachna vigintioctomaculata F. (Coleoptera: Coccinellidae) was recorded by scientists during the 1960's. This coccinellid is a serious pest of potato and in the Shkotovsky region of the Primorsky Territory, $H$. vigintioctomaculata was infected by $B$. bassiana and $B$. tenelle at a frequency of $5.6 \%$ during 1971 and in the Khasan region at a rate of $6.8 \%$ during 1989 . Other coccinellids infected by these fungal pathogens included $C$. septempunctata, $H$. axyridis, Calvia quatuordecimguttata (L.) and Hippodamia tredecimpunctata (L.) (Coleoptera: Coccinellidae). Kuznetsov (1997) summarized that population dynamics of coccinellids in that territory are significantly influenced by parasitoids but not by carnivorous insects, mites, insectivorous birds or entomopathogens.

Yinon (1969) commented on finding adult Chilocorus bipustulatus (L.) (Coleoptera: Coccinellidae) infected by the laboulbenialean fungus $H$. virescens. Larvae of $C$. bipustulatus were also found infected by 'white mycelium' on trunks in citrus groves. However, no supporting data was provided to indicate the prevalence of these diseases in field populations of $C$. bipustulatus. Cottrell \& Shapiro-Ilan (2003) took field-collected, foraging adults of $O$. $v$-nigrum and $H$. axyridis to the laboratory during September and October and found that 33 and $81 \%$, respectively, of $O$. v-nigrum dying within 14 days of collection were visibly infected by $B$. bassiana; no $H$. axyridis that died during that time were visibly infected. In this situation, the likelihood of infection could have been increased by laboratory conditions suitable to the 
pathogen (e.g. constant temperature, decreased UV exposure and high relative humidity) but this does not exclude the fact that the inoculum was present on the insect when collected in the field and the two species were collected from the same areas.

In a study of the laboulbenialean fungus $H$. virescens on coccinellids in Kentucky, USA, Harwood et al. (2006) found that $82.3 \%$ of $H$. axyridis were infected compared with only $4.7,4.2$ and $2.5 \%$ of Psyllobora vigintimaculata Say (Coleoptera: Coccinellidae), Brachiacantha quadripunctata (F.) (Coleoptera: Coccinellidae) and Cycloneda munda (Say) (Coleoptera: Coccinellidae), respectively. Those authors did not recover this ectoparasitic fungus from C. maculata or Hyperaspis signata (Oliv.) (Coleoptera: Coccinellidae). In Georgia, USA, natural infection of $O$. v-nigrum by $H$. virescens is similarly high as for H. axyridis (T. Cottrell, unpubl. data).

Hesperomyces virescens has been reported infecting these coccinellids: Chilocorus stigma Thaxter, C. bipustulatus) (Applebaum et al., 1971; Kamburov et al., 1967), Adalia bipunctata (L.) (Welch et al., 2001), H. axyridis (Garcés \& Williams, 2004), H. convergens (Thaxter, 1931), Cycloneda sanguinea (L.) (Tavares, 1979), Psyllobora spp. (Tavares, 1985), Eriopis connexa Germar (Thaxter, 1931), O. v-nigrum (Weir \& Beakes, 1996), Coccinula crotchi (Lewis) and Coccinula sinensis Weise (M. Majerus \& R. Ware, pers. obs.).

This fungus is often reported on the ventroposterior of males and the dorsoposterior of females; a sexual dimorphism that reflects the major transmission mechanism which is thought to be direct contact during mating (Weir \& Beakes, 1996; Welch et al., 2001; Riddick \& Schaefer, 2005). However, recent studies demonstrated that the distribution of $H$. virescens thalli on aggregating beetles are not explained by sexual transmission (Riddick \& Schaefer, 2005; Riddick, 2006; Nalepa \& Weir, 2007). Nalepa \& Weir (2007) observed that overwintering $H$. axyridis did not exhibit the characteristic elytral distribution of $H$. virescens as hypothesised by the sexual transmission theory. In contrast, fungal thalli were distributed on the anterior part of the body which would accord with direct contact through aggregation and orientation behaviour. A similar pattern was reported for A. bipunctata which, when collected from overwintering aggregations, had fungal thalli distributed at the margins and front angles of the elytra (Weir \& Beakes, 1996). Nalepa \& Weir (2007) conclude that direct transmission through contact with conspecifics is the most important mechanism for transmission of $H$. virescens: sexual contact is of primary importance in the mating season but aggregation in winter also plays a significant role.

Welch et al. (2001) noted spatial variation in the prevalence of $H$. virescens in populations of $A$. bipunctata within London; the prevalence of infection was higher in central London than at the periphery and, indeed, infection was rare or absent in the surrounding area. This short-range (less than $25 \mathrm{~km}$ ) variation in prevalence is unusual but indicates an association between urbanisation and disease dynamics. It is hypothesised that the reported variation is linked to phenology and more specifically elevated urban temperatures increasing the overlap of generations (new generation adults eclosed one month earlier in central London compared to peripheral London) and consequent interbreeding between cohorts.

In summary, the majority of research on the direct interactions between fungi and ladybirds has concentrated on $B$. bassiana because of the potential non-target impact of this fungus when used as a mycoinsecticide against various pest insects. The physiological susceptibility of many species of coccinellids to B. bassiana has been demonstrated and includes: $H$. convergens (James et al., 1995), A. bipunctata (Roy et al., 2008b), C. septempunctata (Roy et al., 2008b), Coleomegilla maculata Timberlake (Todorova et al., 1994, 2000), Serangium parcesetosum Sicard (Poprawski et al., 1998), O. v-nigrum (Cottrell \& Shapiro-Ilan, 2003) and Cryptolaemus montrouzieri Mulsant (Smith \& Krischik, 2000). However, there is still considerable need for data on direct interactions between naturally-occurring fungal pathogens and coccinellid populations.

\section{Sublethal effects}

Sublethal effects of entomopathogens on host insects are varied and knowledge of those effects will depend upon measurements taken. Bauer \& Nordin (1988) documented both a reduced consumptive and nitrogen consumptive index, reduced relative growth rate and reduced gross and net production efficiencies when the Eastern spruce budworm, Choristoneura fumiferana Clemens (Lepidoptera: Tortricidae), was infected with a medium lethal dose of Nosema fumiferanae (Microsporidia). Reduced fecundity as a sublethal effect of infection has been documented for many species (Roy et al., 2006a). However, the sublethal effects of entomopathogenic fungi on coccinellids are rarely known as this phenomenon is rarely studied. Given that insects possess various means to resist pathogens (Tanada \& Kaya 1993), it is likely that sublethal effects of fungi on coccinellids have been overlooked in studies assessing coccinellid mortality.

From the limited data, Poprawski et al. (1998) determined that $B$. bassiana did affect predation of the coccinellid $S$. parcesetosum through reduced voracity of moribund larvae but they did not detect sublethal effects of either B. bassiana (strain GHA) or Paecilomyces fumosoroseus (strain 612) Apopka (Ascomycota: Hypocreales) on development of this predator. Roy et al. (2008b) measured mortality of $C$. septempunctata, $H$. axyridis (populations from Japan and Britain) and $A$. bipunctata and fecundity of the two latter species when exposed to $B$. bassiana (GHA strain). Mortality of both C. septempunctata and $A$. bipunctata were high relative to $H$. axyridis (populations from Japan and Britain). In fact, the $\mathrm{LD}_{50}$ of $H$. axyridis from Japan and Britain were determined to be $10^{8.3}$ and $10^{9.6}$ conidia $\mathrm{ml}^{-1}$, respectively. However, the impact of $B$. bassiana upon $H$. axyridis (Britain) was detected via reduced fecundity at all $B$. bassiana doses tested (i.e., $10^{5}, 10^{7}$ and $10^{9}$ conidia $\mathrm{ml}^{-1}$ ). Roy et al. (in press) suggest that reduced fecundity is indicative of 
fungal infection although mortality is only seen at high doses.

\section{Intra-guild predation}

Intra-guild predation occurs when competing predators engage in a trophic interaction (predation or parasitism) with one another and is prevalent within many communities (Polis \& Holt, 1992; Pell et al., 2008). A number of studies have demonstrated the occurrence of asymmetric and symmetric intra-guild predation between entomopathogens and insects (Roy \& Pell, 2000). This research has largely focussed on the pathogen as the antagonist but, of course, the pathogen can also be preyed upon.

Laboratory experiments have shown that C. septempunctata, Coccinella septempunctata brucki Mulsant (Coleoptera: Coccinellidae) and $H$. axyridis consume aphids at a late stage of Pandora neoaphidis (Remaudière and Hennebert) Humber (Zygomycota: Entomophthorales) (an aphid-specific obligate pathogen) infection (Pell et al., 1997; Roy et al., 1998, 2003, 2008a). These predatory coccinellids could, therefore, have the potential to negatively impact on $P$. neoaphidis. However, in all cases a preference was shown for uninfected aphids although this preference was only marginal for $H$. $a x y$ ridis (Roy et al., 2008a). Furthermore, only H. axyridis consumed entire cadavers; the other species left partially consumed cadavers (Roy et al., 1998, 2008a). Partiallyconsumed cadavers produced significantly fewer conidia but this did not reduce transmission rates (Roy et al., 1998), indeed the presence of a foraging coccinellid greatly increased transmission compensating for the reduction in inoculum caused by feeding damage (Roy et al., 1998).

In contrast, Pell \& Vandenberg (2002) demonstrated that the convergent ladybird, $H$. convergens, avoided feeding on Russian wheat aphids, Diuraphis noxia (Mordavilko) (Hemiptera: Aphididae), infected with $P$. fumosoroseus. Characteristically, this hypocrealean fungal species is a generalist pathogen and could infect coccinellids, therefore, it could be advantageous for foraging coccinellids to avoid infected aphids. It would be interesting to explore whether coccinellids avoid consumption of other hypocrealean-infected cadavers. This would be particularly relevant to extremely polyphagous species such as $H$. axyridis which certainly pose a threat to aphid-specific pathogens through intra-guild predation (Roy et al., 2008a) but could also be preying on other fungal-infected insect cadavers.

\section{INDIRECT INTERACTIONS}

Epizootic development (sudden increase in disease incidence within a population) is dependent on properties of the host population, pathogen population and effective transmission between the two (Fuxa \& Tanada, 1987). The density of the pathogen population is considered to be one of the most important factors in determining whether a disease becomes epizootic (Fuxa \& Tanada, 1987). Epizootics are also host-density dependent but an epizootic can develop at low host densities if the pathogen is widely distributed within the host habitat.
Host and non-host dispersal can be essential for pathogen transmission.

Roy et al. (1998) demonstrated the impact of coccinellid foraging on $P$. neoaphidis transmission within a plant. C. septempunctata increased the movement of the host thus increasing the probability of contact with the pathogen. It is possible that different coccinellid species (and life stages) will evoke distinct defence responses by aphids (Roy et al., 2002). Furthermore aphid species will vary in their defence responses and defence responses will be altered by infection (Roy et al., 1999, 2002, 2006a). Interactions involving multiple species are complex and experiments should be designed to reflect this complexity. The intriguing insights that this research will reveal will undoubtedly be worthwhile.

Roy et al. (2001) have also demonstrated that C. septempunctata can vector $P$. neoaphidis. In the field $C$. septempunctata (inoculated with $P$. neoaphidis conidia) resulted in $5 \%$ of aphids becoming infected in the colonies in which these coccinellids subsequently foraged. It has also been demonstrated that $C$. septempunctata commonly forage in colonies of aphids infected with $P$. neoaphidis (Roy, 1997). Further studies are required to assess the efficacy of this transmission mechanism under natural field conditions and for different coccinellid species. For example, $H$. axyridis is an intra-guild predator of $P$. neoaphidis but does this species also increase transmission over a large spatial scale through foraging widely in aphid habitats?

\section{ARE FUNGAL PATHOGENS IMPORTANT IN THE REGULATION OF COCCINELLID POPULATIONS?}

Most organisms are host to microbial natural enemies but it is important to ascertain whether these diseases have a role in population regulation of species. Disease transmission and, therefore, impact on a population depends on the distribution of the pathogen and its persistence (Ostfeld et al., 2005). Some facultative pathogens are ubiquitous, widely distributed and persistent in stable environments such as the soil. Therefore organisms that spend periods of their life-cycle in those environments can be at risk. For example, hypocrealean fungi can persist in the soil and on vegetation and are infective to many insect species (Roy \& Pell, 2000; Raymond et al., 2005; Meyling \& Pell, 2006).

In a recent study Ormond et al. (2006) demonstrated that about $15 \%$ of overwintering $C$. septempunctata succumbed to B. bassiana infection. However, B. bassiana is rarely reported from other coccinellid hosts in the field (Majerus, 1994). This could be attributed to a number of reasons: high resistance of some coccinellid species to $B$. bassiana (Cottrell \& Shapiro-Ilan, 2003; Roy et al., 2008 b) or lack of contact with the pathogen (in temperate regions $C$. septempunctata spends the winter months in diapause under leaf litter where they are exposed to this fungal pathogen (Majerus, 1994; Ormond et al., 2006) other coccinellids favour alternative overwintering sites such as buildings where the prevalence of pathogens such as $B$. bassiana is likely to be low). However, it could also 
be the consequence of a lack of studies focusing on fungal-coccinellid interactions. Therefore, it is likely that B. bassiana will be an important mortality factor of some species of coccinellid such as C. septempunctata but have less significance to other species that have limited contact with soil or other pathogen rich habitats. Furthermore the relationship will vary both spatially and temporally, for example it is known that insects experiencing suboptimal conditions (stress) are more susceptible to B. bassiana (Fuxa \& Tanada, 1987). The dynamics of pathogens through changing seasons is complex and generally microbial ecology is poorly understood. However, the importance of increasing understanding in this field is becoming even more critical as we face the inevitability of anthropogenically-induced changing environments.

Anthropogenically-induced global environmental change, including climate change and habitat fragmentation, is becoming increasingly implicated as a major threat to biodiversity and the balance of ecological processes in the decline of populations (Balmford, 2005). It is anticipated that infectious diseases in general will increase in prevalence in temperate zones where the climate is predicted to become warmer and wetter (Intergovernmental Panel on Climate Change, 1996). Even modest changes to the environment are expected to have a rapid impact on the distribution and abundance of insects and their associated pathogens because they are physiologically sensitive to temperature and have short life cycles, high mobility and high reproductive potential (Ayres \& Lombardero, 2000). Many insects are already responding rapidly to climate change (Parmesan \& Yohe, 2003) and expanding northwards (Asher et al., 2001; Hickling et al., 2006). This work does not include the effects of climate change on coccinellid distribution and this should be a priority for future research. In addition studies on the broad-scale changes in the dynamics of insect pathogen populations should be a priority for the future.

\section{CONCLUSIONS AND FUTURE DIRECTIONS}

Coccinellidae are a commonly-encountered and easilyrecognized family of insect natural enemies. Although ample research has shown the diversity of natural enemies attacking Coccinellidae, surprisingly little of this information concerns entomopathogenic fungi. Information that can be found mostly relates to the physiological susceptibility of non-target coccinellids to fungal pathogens when these pathogens are formulated as insecticides against insect pests and the rates of fungal infection in overwintering aggregations. Nonetheless, information is beginning to emerge which shows differential susceptibility within native species and between native and introduced species of Coccinellidae to fungi. Fortunately, our understanding of fungal pathogen-coccinellid interactions can be fostered within the context of the already voluminous research done on pest insects and their fungal pathogens. It is likely that the dearth of information regarding the interaction of coccinellids with fungal pathogens has influenced our understanding of coccinellid population dynamics and their resulting predation upon pest populations.

The history of classical biological control using coccinellids is as rich as are the explanations provided for the success or failed attempts to establish natural enemies (van den Bosch et al., 1959, van den Bosch, 1968, Gordon, 1985). However, the role of entomopathogens, including fungi, upon introduced and native species of predators (and parasites) has been largely ignored, whereas, the natural enemy release hypothesis is commonly invoked to explain the successful establishment of pest species (Clay, 2003). Harmonia axyridis is considered an invasive alien species in USA and Europe (Roy et al., 2006b; Brown et al., 2008; Koch \& Galvan, 2008) and has been designated pest status in North America (Koch, 2003). Recent research would indicate that $H$. axyridis is resistant to B. bassiana (Cottrell \& ShapiroIlan, 2003, 2008; Roy et al., 2008b). However, the brief mention by Kuznetsov (1997) that $H$. axyridis was found infected by $B$. bassiana in eastern Russia indicates the need for assaying $B$. bassiana isolates from the native range of $H$. axyridis against populations of the coccinellid from within its native range and from its expanded range in North America and Europe. This approach would indicate if an introduced predator such as $H$. axyridis has benefited from natural enemy release. A similar approach may aid in understanding why another species introduced to North America, C. septempunctata, has been so successful across much of North America. Likewise, we do not understand the impact that the ectoparasitic fungus $H$. virescens may have upon $H$. axyridis in North America, and possibly in Europe, through its negative effect on foraging, flight and mating success. Future research should address the profound absence of knowledge as revealed in this review, specifically the impact of entomopathogenic fungi on natural populations of Coccinellidae, sublethal effects and indirect interactions.

\section{REFERENCES}

Appelbaum S.W., Kfir R., Gerson U. \& Tadmor U. 1971: Studies on the summer decline of Chilocorus bipustulatus in citrus groves of Israel. Entomophaga 16: 433-444.

Asher J., Warren M., Fox R., Harding P., Jeffcoate G. \& JefFCOATE S. 2001: The Millennium Atlas of Butterflies in Britain and Ireland. Oxford University Press, $433 \mathrm{pp}$.

Ayres M.P. \& Lombardero M.J. 2000: Assessing the consequences of global change for forest disturbance from herbivores and pathogens. Sci. Total Environ. 262: 263-286.

Balmford A., Bennun L., ten Brink B., Cooper D., Côté I.M., Crane P., Dobson A., Dudley N., Dutton I., Green R.E., Gregory R., Harrison J., Kennedy E.T., Kremen C., LeaderWilliams N., Lovejoy T., Mace M., May R., Mayaux P., Phillips J., Redford K., Ricketts T.H., Rodriguez J.P., SANJayan M., Schei P., van JaArsveld A. \& Walther B.A. 2005: Science and the Convention on Biological Diversity's 2010 target. Science 307: 212-213.

BARRON A. \& WILSON K. 1998: Overwintering survival in the seven spot ladybird, Coccinella septempunctata (Coleoptera: Coccinellidae). Eur. J. Entomol. 95: 639-642.

BAUER L.S. \& Nordin G.L. 1988: Nutritional physiology of the eastern spruce budworm Choristoneura fumiferana, infected 
with Nosema fumiferanae, and interactions with dietary nitrogen. Oecologia 77: 44-50.

Brown P.M.J., Adriaens T., Bathon H., Cuppen J., Goldarazena A., Hagg T., Kenis M., Klausnitzer B.E., Kovar I., Loomans A.J., Majerus M.E.N., Nedved O., Pedersen J., Rabitsch W., Roy H.E., Ternois V., Zakharov I., Roy D.B., WARE R.L. \& Majerus M.E.N. 2008: Harmonia axyridis in Europe: spread and distribution of a non-native coccinellid. BioControl 53: 5-21.

CAGÁŇ L. \& UhLíK V. 1999: Pathogenicity of Beauveria bassiana strains isolated from Ostrinia nubilalis $\mathrm{Hbn}$. (Lepidoptera: Pyralidae) to original host larvae and to ladybirds (Coleoptera: Coccinellidae). Plant Prot. Sci. 35: 108-112.

Ceryngier P. \& Hodek I. 1996: Enemies of Coccinellidae. In Hodek I. \& Honěk A. (eds): Ecology of Coccinellidae. Kluwer Academic Publishers, Dordrecht, pp. 319-350.

Clay K. 2003: Parasites lost. Nature 421: 585-586.

Cottrell T.E. \& Shapiro-Ilan D.I. 2003: Susceptibility of a native and an exotic lady beetle (Coleoptera: Coccinellidae) to Beauveria bassiana. J. Invert. Pathol. 84: 137-144.

Cottrell T.E. \& Shapiro-Ilan D.I. 2008: Susceptibility of endemic and exotic North American ladybirds (Coleoptera: Coccinellidae) to endemic fungal entomopathogens. Eur. $J$. Entomol. 105: 455-460.

Federici B.A. \& Maddox J.V. 1996: Host specificity in microbe-insect interactions. Bioscience 46: 410-421.

FuXa Y. \& TANada J.R. 1987: Epizootiology of Insect Diseases. Wiley, New York, 555 pp.

Garcés S. \& Williams R. 2004: First record of Hesperomyces virescens Thaxter (Laboulbeniales: Ascomycetes) on Harmonia axyridis (Pallas) (Coleoptera: Coccinellidae). J. Kans. Entomol. Soc. 77: 156-158.

Ginsberg H.S., Lebrun R.A., Heyer K. \& Zhioua E. 2002: Potential nontarget effects of Metarhizium anisopliae (Deuteromycetes) used for biological control of ticks (Acari: Ixodidae). Environ. Entomol. 31: 1191-1196.

Gordon R.D. 1985: The Coccinellidae (Coleoptera) of America north of Mexico. J. N. Y. Entomol. Soc. 93: 1-912.

HAJEK A. 2004: Natural Enemies: An Introduction to Biological Control. Cambridge University Press, Cambridge, 388 pp.

HaJeK A.E., Butler L. \& Wheeler M.M. 1995: Laboratory bioassays testing the host range of the Gypsy moth fungal pathogen Entomophaga maimaiga. Biol. Cont. 5: 530-544.

Hajek A.E., Butler L., Walsh S.A.R., Silver J.C., Hain F.P., Hastings F.L., Odell T.M. \& Smitley D.R. 1996: Host range of the Gypsy moth (Lepidoptera: Lymantriidae) pathogen Entomophaga maimaiga (Zygomycetes: Entomophthorales) in the field versus laboratory. Environ. Entomol. 25: 709-721.

Harwood J.D., Ricci C., Romani R., Pitz K.M., Weir A. \& OBRYCKI J.J. 2006: Prevalence and association of the laboulbenialean fungus Hesperomyces virescens (Laboulbeniales: Laboulbeniaceae) on coccinellid hosts (Coleoptera: Coccinellidae) in Kentucky, USA. Eur. J. Entomol. 103: 799-804.

HibBett D.S., Binder M., Bischoff J.F., Blackwell M., Cannon P.F., Eriksson O.E., Huhndorf S., James T., Kirk P.M., Lücking R., Thorsten Lumbsch H., Lutzoni F., Brandon Matheny P., McLaughlin D.J., Powell M.J., Redhead S., Schoch C.L., Spatafora J.W., Stalpers J.A., Vilgalys R., Aime M.C., Aptroot A., Bauer R., Begerow D., Benny G.L., Castlebury L.A., Crous P.W., Dai Y.C., Gams W., Geiser D.M., Griffith G.W., Gueidan C., Hawksworth D.L., Hestmark G., Hosaka K., Humber R.A., Hyde K.D., Ironside J.E., Kõljalg U., Kurtzman C.P., Larsson K.-H., Lichtwardt R., Longcore J., Miadlikowska J., Miller A., Moncalvo J.M., Mozley-Standridge S., Oberwinkler F., Parmasto E., Reeb V., Rogers J.D., Roux C., Ryvarden L., Sampaio J.P., Schüssler A., Sugiyama J., Thorn R.G., Tibell L., Untereiner W.A., Walker C., Wang Z., Weir A., Weiss M., White M.M.,
Winka K., Yao Y.J. \& Zhang N. 2007: A higher-level phylogenetic classification of the Fungi. Mycol. Res. 111: 509-547.

Hickling R., Roy D.B., Hill J.K., Fox R. \& Thomas C.D. 2006: The distributions of a wide range of taxonomic groups are expanding polewards. Glob. Change Biol. 12: 450-455.

HodeK I. \& HonĚK A. (eds): Ecology of Coccinellidae. Kluwer Academic Publishers, Dordrecht, 484 pp.

IPERTI G. 1966: Protection of coccinellids against mycosis. In Hodek I. (ed.): Ecology of Aphidophagous Insects. Academia Prague \& Dr W. Junk, Dordrecht, The Hague, pp. 189-190.

James R.R. \& LighthaRT B. 1994: Susceptibility of the convergent lady beetle (Coleoptera: Coccinellidae) to four entomogenous fungi. Environ. Entomol. 23: 190-192.

James R.R., Shaffer B.T., Croft B., Lighthart B. 1995: Field evaluation of Beauveria bassiana: its persistence and effects on the pea aphid and a non-target coccinellid in alfalfa. Biocon. Sci. Technol. 5: 425-438.

James R.R., Croft B.A., Shaffer B.T. \& Lighthart B. 1998: Impact of temperature and humidity on host-pathogen interactions between Beauveria bassiana and a coccinellid. Environ. Entomol. 27: 1506-1513.

Kamburov S.S., Nadel D.J. \& KenNeth R. 1967: Observations on Hesperomyces virescens Thaxter (Laboulbeniales), a fungus associated with premature mortality of Chilocorus bipustulatus L. in Israel. Israel J. Agric. Res. 17: 131-134.

KocH R.L. 2003: The multicolored Asian lady beetle, Harmonia axyridis: A review of its biology, uses in biological control, and non-target impacts. J. Insect Sci. 3: 1-16.

Koch R.L. \& Galvan T.L. 2008: Bad side of a good beetle: The North American experience with Harmonia axyridis. BioControl 53: 23-35.

KuzNeTsov V.N. 1997: Lady Beetles of the Russian Far East. Memoir no. 1, Center for Systematic Entomology, The Sandhill Crane Press, Gainesville, 248 pp.

Lacey L.A., Frutos R., Kaya H.K. \& Vail P. 2001: Insect pathogens as biological control agents: do they have a future? Biol. Contr. 21: 230-248.

MaJERus M.E.N. 1994: Ladybirds. Harper Collins, London, 367 pp.

MeYling N.V. \& Pell J.K. 2006: Detection and avoidance of an entomopathogenic fungus by a generalist insect predator. Ecol. Entomol. 31: 162-171.

Nalepa C.A. \& Weir A. 2007: Infection of Harmonia axyridis (Coleoptera: Coccinellidae) by Hesperomyces virescens (Ascomycetes: Laboulbeniales): role of mating status and aggregation behavior. J. Invertebr. Pathol. 94: 196-203.

Ormond E.L., Thomas A.P.M., Pell J.K. \& Roy H.E. 2006: Overwintering ecology of Coccinella septempunctata, Beauveria bassiana and Dinocampus coccinellae. In Walter A.H., Rossing W.A.H., Eggenschwiler L. \& Poehling H.-M. (eds): Working Group "Landscape management for functional biodiversity" at Zürich-Reckenholz (Switzerland), 16-19 May 2006. IOBC/WPRS Bulletin 29(6): 85-88.

Ostfeld R.S., Glass G.E. \& KeEsing F. 2005: Spatial epidemiology: an emerging (or re-emerging) discipline. Trends Ecol. Evol. 20: 328-336.

Parmesan C. \& Yohe G. 2003: A globally coherent fingerprint of climate change impacts across natural systems. Nature 421: $37-42$.

Pell J.K. \& Vandenberg J.D. 2002: Interactions among the aphid Diuraphis noxia, the entomopathogenic fungus Paecilomyces fumosoroseus and the coccinellid Hippodamia convergens. Biocontrol Sci. Techn. 12: 217-224.

Pell J.K., Pluke R., Clark S.J., Kenward M.G. \& Alderson P.G. 1997: Interactions between two aphid natural enemies, the entomopathogenic fungus Pandora neoaphidis Remaudière \& Hennebert (Zygomycetes: Entomophthorales) and the 
predatory beetle Coccinella septempunctata L. (Coleoptera: Coccinellidae). J. Invertebr. Pathol. 69: 261-268.

Pell J.K., Baverstock J., Roy H.E., Ware R.L. \& Majerus M.E.N. 2008: Intraguild predation involving Harmonia axyridis: a review of current knowledge and future perspectives. BioControl. 53: 147-168.

Pingel R.L. \& Lewis L.C. 1996: The fungus Beauveria bassiana (Balsamo) Vuillemin in a corn ecosystem: its effect on the insect predator Coleomegilla maculata De Geer. Biol. Control 6: $137-141$.

Polis G.A. \& Holt R.D. 1992: Intraguild predation: the dynamics of complex trophic interactions. Trends Ecol. Evol. 7: 151-154.

Poprawski T.J., Legaspi J.C. \& Parker P.E. 1998: Influence of entomopathogenic fungi on Serangium parcesetosum (Coleoptera: Coccinellidae), an important predator of whiteflies (Homoptera: Aleyrodidae). Environ. Entomol. 27: 785-795.

RiDDICK E.W. 2005: Influence of host gender on infection rate, density and distribution of the parasitic fungus, Hesperomyces virescens, on the multicolored Asian lady beetle, Harmonia axyridis. J. Insect Sci. 6: 1-15.

RidDick E.W. \& SchaefER P.W. 2005: Occurrence, density and distribution of parasitic fungus Hesperomyces virescens (Laboulbeniales: Laboulbeniaceae) on multicoloured Asian beetle (Coleoptera: Coccinellidae). Ann. Entomol. Soc. Am. 98: 615-624.

Roy H.E. 1997: Interactions Between Aphid Predators and the Entomopathogenic Fungus Erynia neoaphidis. PhD Thesis, University of Nottingham.

Roy H.E. \& J.K. PeLL 2000: Interactions between entomopathogenic fungi and other natural enemies: Implications for biological control. Biocontrol Sci. Techn. 10: 737-752.

Roy H.E., Pell J.K., Clark S.J. \& Alderson P.G. 1998: Implications of predator foraging on aphid pathogen dynamics. $J$. Invert. Pathol. 71: 236-247.

Roy H.E., Pell J.K. \& Alderson P.G. 1999: Effects of fungal infection on the alarm response of pea aphids. J. Invert. Pathol. 74: 69-75.

Roy H.E., Pell J.K. \& Alderson P.G. 2001: Targeted dispersal of the aphid pathogenic fungus Erynia neoaphidis by the aphid predator Coccinella septempunctata. Biocontrol Sci. Techn. 11: 101-112.

Roy H.E., Pell J.K. \& Alderson P.G. 2002: Effect of Erynia neoaphidis infection and coccinellid foraging on the spatial distribution of aphids on plants. J. Invert. Pathol. 81: 127-129.

Roy H.E., Pell J.K. \& Alderson P.G. 2003: Effect of spatial heterogeneity on the role of Coccinella septempunctata as an intra-guild predator of the aphid pathogen Pandora neoaphidis. J. Invert. Pathol. 82: 85-95.

Roy H.E., Steinkraus D., Eilenberg E., Hajek A. \& Pell J.K. 2006a: Bizarre interactions and endgames: entomopathogenic fungi and their arthropod hosts. Annu. Rev. Entomol. 51: 331-357.

Roy H.E., Brown P. \& Majerus M.E.N. 2006b: Harmonia axyridis: A successful biocontrol agent or an invasive threat? In Eilenberg J. \& Hokkanen H. (eds): An Ecological and Societal Approach to Biological Control. Kluwer Academic Publishers, Dordrecht, pp. 295-309.

Roy H.E., Baverstock J., Ware R.L., Clark S.J., Majerus M.E.N., Baverstock K.E. \& Pell J.K. 2008a: Intraguild predation of the aphid pathogenic fungus Pandora neoaphidis by the invasive coccinellid Harmonia axyridis. Ecol. Entomol. 33: $175-182$

Roy H.E., Brown P.M.J., Rothery P., Ware R.L. \& Majerus M.E.N. 2008b: Interactions between the fungal pathogen Beauveria bassiana and three species of ladybird: Harmonia axyridis, Coccinella septempunctata and Adalia bipunctata. BioControl. 53: 265-276.

SANTAMARIA S. 2001: Taxonomy and morphology of Amorphomyces (Laboulbeniales). Mycol. Res. 104: 1389-1398.

Shapiro-Ilan D.I. \& CotTrell T.E. 2005: Susceptibility of lady beetles (Coleoptera: Coccinellidae) to entomopathogenic nematodes. J. Invert. Pathol. 89: 150-156.

SMITH S.F. \& KRISCHIK V.A. 2000: Effects of biorational pesticides on four coccinellid species (Coleoptera: Coccinellidae) having potential as biological control agents in interiorscapes. J. Econ. Entomol. 93: 732-736.

Solter L.F. \& MAddox J.V. 1998: Physiological host specificity of Microsporidia as an indicator of ecological host specificity. J. Invert. Pathol. 71: 207-216.

Tanada Y. \& KaYa H.K. 1993: Insect Pathology. Academic Press, San Diego, 666 pp.

TAVARES I.I. 1979: The Laboulbeniales and their arthropod hosts. In Batra L.R. (ed.): Insect-Fungus Symbiosis: Nutrition, Mutualism, and Commensalism. John Wiley \& Sons, New York, pp. 229-258.

TAVARES I.I. 1985: Laboulbeniales (Fungi, Ascomycetes). Mycol. Mem. 9: 1-627.

THAXTER R. 1931: Contribution towards a monograph of the Laboulbeniaceae. Mem. Am. Acad. Arts Sci. 16: 1-435.

Todorova S.I., Côté J.-C., Martel P. \& Coderre D. 1994: Heterogeneity of two Beauveria bassiana strains revealed by biochemical tests, protein profiles and bio-assays of Leptinotarsa decemlineata (Col.: Chrysomelidae) and Coleomegilla macultata lengi (Col.: Coccinellidae) larvae. BioControl 39: 159-169.

Todorova S.I., Cote J.C. \& Coderre D. 1996: Evaluation of the effects of two Beauveria bassiana (Balsamo) Vuillemin strains on the development of Coleomegilla maculata lengi Timberlake (Col., Coccinellidae). J. Appl. Entomol. 120: 159-163.

Todorova S.I., Coderre D. \& Cote J.C. 2000: Pathogenicity of Beauveria bassiana isolates toward Leptinotarsa decemlineata (Coleoptera: Chrysomelidae), Myzus persicae (Homoptera: Aphididae) and their predator Coleomegilla maculate lengi (Coleoptera: Coccinellidae) Phytoprotection 81: 15-22.

UNDEEN A.H. \& MADDOX J.V. 1973: Infection of nonmosquito host by injection with spores of the microsporidan Nosema algerae. J. Invert. Pathol. 22: 258-265.

Van den Bosch R., Schlinger E.I., Dietrick E.J., Hagen K.S. \& Halloway J.K. 1959: The colonization and establishment of imported parasites of the spotted alfalfa aphid in California. $J$. Econ. Entomol. 52: 136-141.

VAN DEN BosCh R. 1968: Comments on population dynamics of exotic insects. Bull. Entomol. Soc. Am. 14: 112-115.

Watson R.T., Heywood V.H., Baste I., Dias B., Gamez R., Janetos T., ReID W. \& RuARK R. 1995: Global Biodiversity Assessment. Cambridge University Press, Cambridge, 1140 pp.

WeIR A. \& Beakes G.W. 1996: Correlative light- and scanning electron microscope studies on the developmental morphology of Hersperomyces virescens. Mycologia 88: 677-693.

WeIR A. \& Hammond P.M. 1997: Laboulbeniales on beetles: host utilization patterns and species richness of the parasites. Biodiv. Conserv. 6: 701-719.

Welch V.L., Sloggett J.J., Webberley K.M. \& Hurst G.D.D. 2001: Short-range clinal variation in the prevalence of a sexually transmitted fungus associated with urbanisation. Ecol. Entomol. 26: 547-550.

YINON U. 1969: The natural enemies of the armored scale ladybeetle Chilocorus bipustulatus (Col. Coccinellidae). Entomophaga 14: 321-328.

Received October 11, 2007; revised and accepted December 4, 2007 